\title{
Under the New Situation of the Textile Economy
}

\author{
Wenzhuan Sun \& Junying Tian \\ College of Textile, Tianjin Polytechnic University \\ Tianjin 300160, China
}

\begin{abstract}
China's entry into the WTO, all the textiles with the formal abolition of restrictions on Chinese textile and garment industry entered the free trade era, the increasingly fierce international competition, but also brought unprecedented opportunities to the Chinese textile and apparel industry. China's textile and garment industry required in this particular under the new situation to meet the challenges and seize the opportunity to be successful. Under the new situation China's textile and garment industry facing difficulties and the opportunities this article will do a specific analysis and put forward some feasible options for enterprises to adopt.
\end{abstract}

Keywords: New situation, Difficulties and opportunities, Possible options

\section{Foreword:}

China entered the WTO, the implementation of a 40-year-old global textile trade quota system was officially abolished, the world ushered in the global textile and garment field of free trade competition. However, after only four months, the United States and Europe also picked up a big stick of trade protectionism for the Chinese export of textiles quotas. On May 27, The EU also announced that on China's two categories of textiles it would start an emergency of special protective procedures. After seven rounds, on November 8, 2005, the two sides reached a "trade in textiles and clothing on the Memorandum of Understanding", In the agreement the product base of 2006 is the related products in 2005 which are inputted to the United States from China. The base of 2007 and 2008 is respectively the volume of annual agreement. The rate of agreement products in 2006 grows from $10 \%$ to $15 \%, 12.5 \%$ to $16 \%$ in $2007,15 \%$ to $17 \%$ in 2008, the agreement in January, 2006 came into effect, and in 2008 December 3 it was terminated.

The first textile agreement indicators which Europe and the United States set limits on the products imported in 2007 was a more reasonable price, but in the allocation method has increased the threshold. According to the "Agreement Tender Notice", provided for a specific period of time restrictions business must have the export performance on the countries and regions, will it be possible to obtain agreement qualified tender. Agreement tender improve eligibility threshold so as to bring the decrease in the number of bidding companies, in 2007 a total of 4787 companies received the US-bound exports to the EU agreement on 13 categories of tender qualifications, less than 16,000 reduction in 2006.

Can be seen, with the increase in international trade in textiles, the problem that China's textile exports is facing, in particular the trade friction, is also increasing, and only the first three quarters of 2006 had reached 70. In 2007, a severe trade friction will continue. Research on the status quo of China's textile trade, especially China's textile trade friction problem, is of great practical significance.

\section{The status quo of China's textile and garment trade}

China is the world's largest textile producer. China's textile and garment industry in the global textile and apparel trade occupy a pivotal position. In the reform and opening up 20 years (1978-1998) China's textile and garment industry reached exports 3566 billion U.S. dollars totally, the net foreign exchange earnings 2550 billion U.S. dollars, and are china's big and major net foreign exchange earnings industries. 20th century since the 90 's, China's textile and garment export growth was mainly on non-quota areas, from 1990 to 1998, the net increase amounted to 22 billion U.S. dollars. One of exports to Japan grew by seven billion U.S. dollars, while the quota-free market increased by only 610 million U.S. dollars. Quota exports in 1998 total exports accounted for 22\%, non-quota exports 78\%. Joining the WTO, because of quota restrictions in 2003 on the United States and the European Union China's textile and apparel exports still account for only $23 \%$ of all exports. China's main textile and apparel export countries and regions are the United States, Japan, Hong Kong, Korea and Australia.

In 2006, China's textile and apparel imports and exports reach 65.136 billion U.S. dollars, grew by 22.66 percent compared to 2005, represent the country's total import and export volume of $9.38 \%$, induce a trade surplus of 29.034 billion U.S. dollars. Of the main textiles and garments export countries (regions), the United States ranked first, the European Union, Japan and China, Hong Kong respectively ranked second, third and fourth. Exports on the United States, Japan and Hong Kong totaled 60.639 billion U.S. dollars, accounting for China's textile and apparel exports of 
$41.23 \%$ of the total. In the main importing countries (regions), Japan listed first, China Taiwan second and South Korea third.

\section{The international environment and the challenges China's textile trade faces}

\subsection{Unprecedented opportunities China's textile exports are facing}

First of all, the production capacity further releases, market space continues to expand. A long time, because of quota restrictions on Chinese textile and garment products in the international market, cost and quality advantages have not been fully released. With the phasing out of quotas, China's textile and garment exports grow steadily.

Secondly, the Chinese textile and garment industry will attract more foreign capital, advanced technology, advanced management, such as elements, strengthen cooperation with countries in the textile and apparel in the field of cooperation in promoting China's textile and garment industry in quality, management, environmental protection, brand development, etc. and promote industrial upgrading.

Thirdly, it can promote Chinese high-tech textile technology and textile machinery exports, so that Chinese textile and garment enterprises by virtue of their relatively strong financial and technical advantages go to North America, Central and South America, Africa, the Middle East, Europe and surrounding countries and regions to invest and set up factories, create diversified markets.

\section{2 challenges China's textile trade faces}

\subsubsection{China's textile industry's problems in present}

Although China's textiles in the world textile trade is playing an important role, but the president of the textile industry Association Du Yu zhou repeatedly in his speech said that China's textile industry take a new road to industrialization, in terms of their specific circumstances or situation at home and abroad there are many contradictions and problems must be addressed.

First of all, China's textile industry's science and technology content is not high, it is difficult to adapt to the competitive environment of the new era of globalization. Contemporary textile industrial restructuring is different from the characteristics of the previous economic era, and it is based on industry-based transnational horizontal division of labor dominant mode of production. What transfer to developing countries are low-end industrial chain technology, such as conventional capacity and equipment, and developed countries still control the commanding heights of technology, brand, market. China's textile industry need to improve its position as worker or the advanced workers, in another words, upgrade the status of the upcoming Chinese manufacturers rose to Chinese brands. The new technology is good enough for those who rose to originality must be put to use high technology to transform traditional industries as the main line of industrial upgrading and structural adjustment of the focus. China's textile enterprises overcome ills such as overweighting the hardware and underweighting software, re-expanding the scale of light Stalls investment in research and development; emphasis on technical management but neglect to management Not only to control low-level redundant construction, and but also the phenomenon of the first-rate equipment, second-rate products, third-rate price is also to be fundamentally changed.

Secondly, the current profitability of our textile industry is not strong. Analyzing the 2003 profit growth factor, we find two main factors, firstly, large-scale use of migrant workers, low wage level; secondly, good results of the years of reform. In 2003, Enterprise management fees and financial costs are lower according to the date analysis from January to November. Comparing sales revenue to the cost, it will be found that the value of the products is not high, the cost of increased risk of resistance is not strong, and this is the main performance of the low labor productivity.

Thirdly, the effectiveness of China's textile industry's fiber resources and energy should be further improved. The development of fiber materials science, improving capacity of fiber resources on performance and functionality, in process, large-scale use of emerging scientific and technological achievements, to greatly improve the efficiency of resource use, reducing consumption, studies fiber and other renewable raw materials and recycling technologies so as to reduce energy consumption and save fiber, all of this are questions to be resolved urgently.

Finally, the popularity of eco-technology in China's textile industry spread quickly in exports, but it has a great difference seen from the whole industry. Implementing eco-standards and environmental standards, is not only for export, but also for the quality of life of consumers at home and abroad, so we have to adhere to the principles of people-centered, protect the environment and sustainable development, need to go through difficulties on materials, equipment, technology, training, investment, etc. and overcome the ideological, technical, material, institutional difficulties.

\subsubsection{International challenges Chinese textile industry faces}

Although the global textile trade quotas will eventually be in the January 2008 cancelled, but the international environment that China is facing is not so easy, all developed countries will make use of a variety of barriers and 
implementation of anti-dumping to carry out trade protectionism policy in order to set restrictions on China's textile export. Many countries have also asked for a postponement or even cancellation of the quota period. China's textile and garment export enterprises should pay special attention to the following questions:

Firstly, it is the Istanbul Declaration. March 2003, Turkey, Mexico, the United States textile industry organizations proposed the Istanbul Declaration requesting WTO to continue to apply quotas management on China's textile export until the end of 2007, and assess the competitiveness of Chinese textile exports.

Secondly, it is about safeguards of special products and textiles. According to Protocol 16 (Special Products safeguards) and the report of the Working Group 242 (textile safeguard measures) which China promise when she joined WTO, so far, the United States, the European Union, Korea, Japan, Canada, India, one after another set domestic legislation in accordance with section 242, the United States has re-imposed restrictions for the three Chinese textiles (knitted fabrics, bras, dressing gowns).

Thirdly, it is anti-dumping investigations. Now India, Turkey, Peru, South Africa and other developing countries have an anti-dumping and anti-dumping investigation on China's textile products, the EU are also brewing some plan including anti-dumping and other restrictive measures.

Fourthly, it is ecological criteria such as technical barriers to trade. Developed countries have formulated and promulgated a series of eco-textile standards. In particular, the European Union in September 11, 2003 implemented Directive 2002/61/EC banning 22 kinds of azoic dyes, June 30, 2004 , blue dye formal implementation instructions on textile was come into effect, making the very stringent requirements for raw materials.

Fifthly,it is SA8000 social responsibility standards. At present, the developed countries, especially Europe and the United States and other politicians within the country, the media, social organizations continue to exert pressure on the government to require exporters of textiles and garments in the production process not to employ child, call for test on the workers working conditions and benefits.

\section{China's textile trade friction problem}

\section{1 textile trade friction phenomenon}

January 1, 2005, although global textile trade quota system is abolished, the United States and Europe settled restrictions against Chinese textiles once again; trade friction happened frequently, there were lots of incidents about textile trade friction in 2005.

\subsection{Reasons of the textile trade friction}

\subsubsection{The re-emergence of protectionism in global trade}

The reason why the re-emergence of protectionism is the only superpower the United States has gradually lost its absolute superiority in the world economy, has been unable to maintain hegemony. Holding highly the big stick of sanctions the United States points it to Europe and Japan, South Korea whose economy gradually restored Seventies twenty-first century and today's major developing countries - China.

\subsubsection{Trade thought transferring from "free trade" to "fair trade", "managed trade"}

70s after the 20th century, European countries restored the economy, improved international competitiveness, the United States after World War II, firstly face a serious problem in international economic competition, and gradually lose its comparative advantage in international trade, its hegemony has become increasingly frail, the United States began to comply with the "reciprocity" principle, rather than the principles of GSP, to deal with trade issues among countries. In this context, the United States Ronald Reagan and George W. Bush have gradually deviated from the ideology of free trade principles in terms of trade theory and trade thought, began to resort to the so-called fair trade and managed trade. But "fairness" is relative, the developed countries use fair competition of their domestic markets as a pretext to achieve its restrictions on foreign merchandise to protect its own industry, this is the strong place "fair trade" has itself.

\subsubsection{Politics of international trade are an important of element}

Trade itself contains the economic factors and political factors, not only involved in international politics, it also has something to do with domestic politics. In theory, politicians know that free trade is superior to the protection of trade. However, on the one hand, they want to seek their own benefits ingenuity, and their benefits come from different groups, especially the major economic blocs. In the era during which international competitiveness of domestic enterprises relatively decline, the economic interests of business groups is likely to conflict. On the other hand, politicians have to win the election; it must yield to some special economic blocs.

\subsection{The impact of Textile trade friction}

\subsubsection{On the impact of China's textile industry}

The textile industry belongs to labor-intensive industries, is a competitive industry in the international market. 
Restricted or is likely to impose restrictions of the product of The first half of 2005 will reach $1 / 3$ of the total amount of textile and apparel exporting to European and American. Restrictions of China's textile products have significant impact on employment.

In addition, the disputes between China, the United States and Europe in textile trade brought to the market more uncertainty. In the international low-end market Chinese textiles are not an irreplaceable competitiveness. Bangladesh, the Philippines, Indonesia, Cambodia, India and other countries have their own advantages. Once China fail in the trade dispute between the United States and Europe, countries mentioned above have the capacity to absorb market orders. Moreover, China's textile industry has a large number of foreign-funded enterprises, once the export setbacks; it will lead to the loss of foreign investment.

4.3.2 Can not be optimistic about the situation in textile exports

In September 5, 2005, Although China and the EU reached an agreement on Chinese textiles in respect to EU customs problem on stranded harbor: all about 80000000 Chinese textiles stranded in the EU customs will be released. For such a result, media defined it as "win-win", but it should be clearly recognized that this is a temporary and limited "win-win." the situation of the China's textile exports to EU in 2008 is not optimistic.

Firstly, in 2005, before 4 months, the Chinese textile exports to the EU doubled, resulting that European Union adopted a "special safeguard" measures to investigate; In June 11,2005 EU and China reached "China-EU textile agreement", before January 1, 2008, there is $8 \%$ year-on-year $12.5 \%$ growth on 10 categories of Chinese textiles in the quota limit. The amount of such growth, as opposed to China's textile production capacity, would be tantamount to a drop in the bucket, so in 2006 the war of quota is more intense.

Secondly, in 2005 the "textile war", many export enterprises get clearance exports, launch price war, its profit is extremely low, and some even losses. Currently, some banks have been extending loans to enterprises of the textile very tightly, and even non-credit phenomenon. Some bank sectors think, China's textile industry may collapse. In fact, China's textile industry is very competitive in the world; dealing with EU textile limits requires upgrading, industrial upgrading, while textile enterprises need more support from the bank.

Thirdly, the EU will amend countervailing law as soon as possible to apply to China. Compared with the anti-dumping and safeguard measures, special safeguard measures for textiles is more powerful, but the power of the textiles-specific safeguard measures in the end of 2007 fails, and more powerful countervailing law is bound to be used by the EU. The EU is now considering granting China half-market economy status, at that time the EU anti-subsidy law will automatically apply to Chinese. EU Trade Commissioner Peter Mandelson said the EU market in 2008 will have the full liberalization of Chinese textile products. But even in 2008, domestic situation of 25 member countries comprising the European Union's is uneven; the textile industry in the EU will have a considerable share, and the EU will not automatically give up.

Fourthly, because China's textile exports to the European Union is uncertain, the EU importers will import from India, Bangladesh and other countries to reduce unnecessary trouble.

\section{China's textile trade measures}

In the face of the grim situation under which the trade frictions often happen after the abolition of 'ATC', the Chinese Government attached great importance, the Ministry of Commerce director of the textile start immediately trade negotiations with the countries concerned, and finally has made gratifying results. First of all, in June 11, 2005 Chinese Trade Representative and the EU reached a "part of Chinese textile exports to the EU memorandum" agreement. And after seven marathon talks, in November 8, 2005, china and the United States reached "regarding trade in textiles and clothing a memorandum of understanding." The signing of these two agreements not only broke the world report of the Working Group terms of paragraph 242 of the $7.5 \%$ limit, but also generate a stable and predictable trade environment for Chinese textile enterprises, and effectively safeguard the interests of China's textile enterprises. Since these two agreements get the overall higher growth rate, so that in 2005 China's textile and garment export has achieved 15.01 billion U.S. dollars, up to one more than one hundred billion U.S. dollars mark for the first time of great achievements. But we should realize that this is not a "once and for all" thing. As long as our country has a comparative advantage of low-cost, high degree of dependence on the textile industry's external surplus, and large trade imbalances continue to exist, thus it is difficult to avoid trade friction. Moreover, after 2008, "transition period product-specific safeguard measures" against China will continue to implement until 2013, as well as non-market economy status gets China's enterprises at a disadvantage in responding to long-term anti-dumping cases. Therefore, China's textile export enterprises and government departments still have many questions to be settled urgently.

\subsection{China's textile enterprises in response to}

\subsubsection{Adjust and optimize the structure of the export of textiles}

The comparative advantages of Chinese textile products are a large quantity and cheap, although quality increase 
year-on-year, the overall level is still in the middle. Because of continuous low-level expansion of production capacity it has been shown oversupply; as a result, in the fierce international market competition it mainly relies on low prices to expand sales. This will not only lead to restrictions that developed countries take such as the United States and Europe means, but also lead a similar level of textile exports of developing countries to take the necessary means to resist China. To solve this problem completely, China's textile enterprises need to improve product development and design capabilities, and promote the product mix optimization, focus on innovation, enhance the technological content and value-added products, speed up the implementation of brand strategy, and vigorously to change the only way to expand sales increasing the number of growth and make low-end processing trade with only modest sales gains.

\subsubsection{The implementation of the strategy of market diversification}

The United States and the European Union are the world's largest textile and apparel import market, also are the China's main textile and apparel export market for many years, Chinese textile products in the U.S. market share has increased year by year, has been as high as $20 \%$, in the EU market it accounted for about $14 \%$, both rank first. Because China's textile exports market heavily relies on the United States and Europe, trade friction between china, the United States and Europe in 2005 frequently happened, seriously affecting the normal operation of China's textile order. Therefore, China's textile export enterprises must appropriately adjust the target market, with the exception of seeking to continue to consolidate the market in the United States and Europe, should we must also actively explore the implementation of the strategy of market diversification, such as Australia, Russia, Switzerland and the Middle East country who have not been restricted and so on, are new customers we should try to develop in order to diversify market risks. That is, "Can not put the whole eggs in one basket," in case the trade environment faces the event of a sudden, you were caught by surprise, so that the whole business gets in a difficult position.

\subsubsection{Qualified textile enterprises go out to the country without export constraints}

At present, the domestic textile industry exports in the face of various constraints should have a new breakthrough in the business strategy, conditional textile and garment enterprises may go outside to set up production plants, will not only ease the trade frictions and a variety of risks brought about by trade environmental uncertainty, help enterprises make better use of both domestic and foreign resources, optimize the allocation of resources and access to advanced technology, management expertise and marketing network, and enhance the international competitiveness of enterprises.

5.1.4 The implementation of both domestic and international market strategies for Chinese textile and garment industry are the development of direction

Textile enterprises should be in operation both inside and outside. Attaches great importance to the domestic market, make full use of their advantages and become the dominant domestic market, which is the basic law of the development of the world's textile and garment industry. with China's rapid economic sustainable development and the general standard of living of the people continuing to improve, China's domestic market potential should not be underestimated, expanding domestic demand is an important force which drives China's textile industry for sustainable development.

\subsection{The responsibility of Government in the textile trade}

Government should create a good, relaxed policy environment for the enterprises to participate in international competition in the market, remove constraints and factors of disharmony, it is necessary to further strengthen the service function. China's textile trade will face a variety of trade frictions and new challenges, the Government should do the following well on macro-control and development strategy.

(1) it is necessary to actively guide the textile industry pay close attention to improve textile product development and design capabilities, and promote upgrading of product structure, block the low-level redundant construction, strengthen supervision whether textile enterprises comply with national labor, environmental protection and safety production or not and management of relevant laws and regulations, emphases the control of textile and garment exports quantity and price, stop vicious competition between enterprises.

(2) We should carefully examine the necessary condition, market access standards and certification system for operating textile and garment export trade in order to improve the overall quality of the textile enterprises and business technology professional level in operating foreign trade.

(3)We should actively implement strategy of "going out" for textile enterprises, the Government should grant encouragement and related support on policy.

(4)We should perfect laws and regulations which has relation to textile trade, in particular, speed up amendments to a simultaneous development of market-oriented process, speed up the decentralization from the Government to industry associations, so that the latter has the related laws and regulations when carrying out various tasks . 


\subsection{Textile Industry Association responses}

Industry associations, chambers of commerce are all non-governmental organizations, they act as a bridge between the government and enterprises. On the one hand, it assists the Government in implementing policies and regulations relating to the implementation and supervision, on the other hand, it represents the interests of the business to provide recommendations and provide advice for Government's policy measures, and gives communication, coordination, self-discipline and anti-dumping Shanghai (should be), etc. v. Service for business. In the past, under the planned economic system, all economic activities were controlled by the Government, Government and enterprises were bounded together. With the reform and opening-up policy and the transition of China's economic system to market economy, various industry associations and chambers of commerce launched and increasingly played more important role. In face of the new international economic situation during which the post-quota era of the textile trade begin, it is very necessary to strengthen organizations of our industry association to fully mobilize and exert its role.

\section{Conclusions}

In short, in the new circumstances, Chinese textile and apparel industry is facing unprecedented opportunities and challenges. We must deeply analyze and understand the current world economic situation, put our own business into correct position, take care of business difficulties encountered by each other and find a suitable program of its own development in today's more fierce competition.

\section{References}

Amable, B. (2000). International specialization and growth, Str.Change Econ. Dyn., 11: 413-431.

Anson, R. (2004). World textile and apparel trade and production trends, Text. Outlook Int., 113: 14-95.

Aqurno, A. (1981). Change over time in the pattern of comparative advantage in manufactured goods: An empirical analysis for the period 1972-1974, Eur. Econ. Rev., 15: 41-62.

Chen, C. and Shih, H. (2004). The impact of WTO accession on the Chinese garment industry. J. Fashion Mark. Manage., 8 (2), 221-229.

China Stati Stical Yearbook, 2004. China Statistics Press, Beijing, PR China.

Du, Y. Z. (2003). A brief introduction of China textile industry 2002. China National Textile Industry Council. Retrieved November 8, 2003, from http://www.cntextile.com/cntex/english2/2002 du.htm.

Kilduff, P., Jiang, H., and Chi, T. (2004). An Analysis of Development Dynamics in the Chinese Textile and Apparel Industries since 1978, 83rd Textile Institute World Conference, Oral Presentation Paper, May 2004.

Noiusis, M. J. (2002). SPSS 11.0 Guide to Data Analysis, 1st ed.. Prentice Hall, Upper Saddle River, NJ.

Zhang, J. (2002). Status Quo and Development of Chinese Textile Chemicals Industries. Presentation paper at China Chemical Industry Conference, Chemical Week Associates, Conferences and Trade Shows. Retrieved March 30, 2004. 